\title{
'n Homilie oor geloofsonderskeiding in 'n akkoord van drie
}

\author{
Author: \\ J. Christo van der Merwe ${ }^{1}$ \\ Affiliation: \\ ${ }^{1}$ Reformed Theological \\ College, University of \\ Pretoria, South Africa \\ Correspondence to: \\ Christo van der Merwe \\ Email: \\ christo.vandermerwe@ \\ up.ac.za \\ Postal address: \\ Private Bag X20, Hatfield \\ 0028, Pretoria, South Africa \\ Dates: \\ Received: 25 Apr. 2012 \\ Accepted: 08 June 2012 \\ Published: 22 Aug. 2012 \\ How to cite this article: \\ Van der Merwe, J.C., \\ 2012, "n Homilie oor \\ geloofsonderskeiding \\ in 'n akkoord van drie', \\ HTS Teologiese Studies/ \\ Theological Studies 68(1), \\ Art. \#1259, 8 pages. http:// \\ dx.doi.org/10.4102/hts. \\ v68i1.1259
}

(C) 2012. The Authors.

Licensee: AOSIS

OpenJournals. This work

is licensed under the

Creative Commons

Attribution License.
A homily on discernment of faith in a chord of three. This article reflects on discernment as a key Christian faith practice of the believing community that wants to live according to its vision and mission as articulated in 1 Peter 2:21: To this you were called, because Christ suffered for you, leaving you an example, that you should follow in his steps. This homily is presented as a chord consisting of three notes that entices the readers to contribute their own harmonies - to witness to their own contexts of tension between true and false prophecy, to choose for God's presence in Jesus Christ and to perservere as followers of Jesus amid the coldness and cruelty of this world. These disciples choose Jesus in spite of the chaos in their own lives and in their world. A similar choice was made by one of the criminals on the cross alongside Jesus (Lk 23:42). The three notes that make up the chord are: discernment on the basis of the Bible with the guidance of the Holy Spirit in order to distinguish the will of God for the road ahead.

\section{Die openingsakkoord}

Op 01 Januarie 2012 het ek die benoeming as nuwe hoof van die Hervormde Teologiese Kollege (HTK) aan die Fakulteit Teologie, Universiteit van Pretoria, aanvaar. Binne die eerste maande was ek verantwoordelik vir drie openingsredes wat in die vorm van homilieë aangebied is. Die eerste was 'n preek waarmee die akademiese jaar van die HTK op 15 Februarie 2012 geopen is. Die tweede geleentheid was die legitimasieplegtigheid van pas afgestudeerde studente van die Nederduitsch Hervormde Kerk van Afrika (NHKA) waartydens hulle as proponente van die NHKA beroepbaar gestel is. Dit was ' $n$ kanselrede binne ' $n$ akademiese konteks. Die derde geleentheid, op 01 April 2012, was 'n Palmsondagerediens waartydens ek op uitnodiging van die Kerkraad van die Nederduitsch Hervormde Gemeente Pretoria-Oos die prediking waargeneem het.

Hierdie drie kanselredes was my eerste formele optredes in my hoedanigheid as hoof van die HTK. Soos die drie note ' $n$ musiekakkoord vorm, vorm hierdie drie redes 'n eenheid. Die eerste homilie in die akkoord van drie word opgedra aan 'n gewaardeerde kollega, prof. dr P.M. Venter, hoogleraar Ou-Testamentiese Wetenskap, by geleentheid van sy emeritaatsaanvaarding. Sy vertrek en my begin geskied nie in 'n vakuum nie. Ons is albei ampsdraers in die NHKA, 'n kerk wat in die huidige tydsgewrig in 'n maalkolk van politieke en teologiese spanning vasgevang is. My voorganger, die eerste hoof van die Hervormde Teologiese Kollege, prof. dr T.F.J. Dreyer, het die oorsaak van hierdie maalkolk uitgewys as die 'kwantumsprong' (Van Aarde \& Dreyer 2011:8) wat die NHKA gemaak het om die evangeliese eis te gehoorsaam om 'n inklusiewe missionale kerk vir die toekoms te wees. Dit vorm die subteks van al drie homilieë - 'n subteks wat tussen die reëls gelees en self ingevul sal moet word.

Dit is gepas om in 'n huldigingsbundel ter ere van ' $n$ Ou-Testamentikus met ' $n$ homilie uit die Ou Testament te begin. Die eerste van die drie note in die akkoord is ' $n$ homilie wat gelewer is by geleentheid van die opening van die Hervormde Teologiese Kollege. Dit teks was uit die Ou Testament, naamlik uit Jeremia 28. Die tema was dié van die 'ware/valse profeet'. Tydens die legitimasieplegtigheid was die teks vir die homilie, die tweede noot in die akkoord van drie, uit Matteus 24. Dit is 'n gedeelte met 'n duidelike Ou-Testamentiese motief as dekor waarin kerk en wêreld 'encountered Christ in the persons of those suffering Christians who have faithfully carried out their mission to the world' (Garland 2003:240). Die derde noot in die akkoord van drie, die kanselrede op Palmsondag 2012, het 'n eweneens sterk Ou-Testamentiese agtergrond. Die tema is, soos in die geval van die ander twee homilieë, oor keuse en die motief kom uit Lukas 23, spesifiek Jesus se laaste kruiswoorde.

\section{Die eerste noot: Jeremia 28:1-17}

Jeremia 28 is wat Crenshaw (1983:172-129) noem "n lewende tradisie'. Dit is asof die leser getuie word van die toneel waarin formidabele profete teenoor mekaar te staan kom. Aan 
die een kant staan Gananja, seun van Assur uit Gibeon en aan die ander kant Jeremia, seun van Hilkia, uit Anatot. Dit is ' $n$ konfliksituasie. Gananja is eerste aan die woord. Hy verkondig ' $n$ positiewe boodskap van hoop:

Luister Israel, die Here gaan die juk van Babel van julle nek afhaal en dit stukkend breek. Nog net twee jaar en al die voorwerpe wat koning Nebukadneser hier uit die tempel weggevoer het, sal teruggebring word, so-ook koning Jojagin van Juda en al die ballinge van Juda. Die Here sal dit doen. (Jer 28:2-4)

So 'n verblydende boodskap behoort die hoorders opgewonde te stem. Hierdie soort boodskap berus op 'n sterk teologiese tradisie, genaamd die Sionstradisie (kyk na Roberts 1973). Hiervolgens sal die Here, die Almagtige, die God van Israel, self die volk in Sion, in Jerusalem, bymekaar bring.

Profete het die boodskap reeds voorheen verkondig. Skaars ' $n$ eeu tevore het ' $n$ groot figuur soos Jesaja feitlik dieselfde gesê. Yates (2009:1 van 32) wys daarop hoe Jesaja se vooruitskoue op die herstel van Sion 'captured the human imagination and expressed the longings of the human heart' en argumenteer verder dat dit 'also had a major influence in shaping the Christian vision'. Hierdie 'visie' kan beskryf word as ' $n$ 'willingness to live with tension' (Yates 2009:32 van 32).

Soos die profete voor hom, bevestig Gananja dus dat God genadig teenoor die volk sal optree. Volgens die SuidAfrikaanse teoloog, Dirkie Smit (1985:99), is die spanning daarin geleë 'dat daar eintlik geen verskil tussen Gananja en Jeremia is nie.' Hy haal Aalders (1934) soos volg aan:

Hannanja moet natuurlijk van zekerheid ... ten volle overtuigd zijn geweesd ... zelf moeten wij verder gaan en aannemen dat hij ook inderdaad zijn rotsvaste overtuiging voor een door God gewerkte hield, in de bezieling van zijn persoonlijke een Goddelijke openbaring zag. In zoverre bestaat er geen enkele reden om de goede trouw van zulk een man in twijfel te trekken. Hij misleide anderen, maar in eerste plaats zigzelf. (bl. 88)

Die naam Gananja, wat beteken 'die Here is genadig', is ironies. Gananja het sy preek tot 'n dramatiese hoogtepunt gevoer. Hy vat die houtjuk wat Jeremia as simbool gedra het en breek dit stukkend. Sy preek eindig op 'n dramatiese noot. Sy optrede is so indrukwekkend dat Jeremia feitlik niks daartéén kan sê nie. Jeremia se eerste woord is 'amen', wat iets soos 'mag dit so wees' beteken. Die leser weet nie of dit opreg of sarkasies bedoel is nie. Van Selms (1974:46) stel dit soos volg: 'Door 'Amen' ('stellig!') betuigt men zijn instemming met een vloek, een bevel of een doxologie en neemt deze voor eigen rekening'. Volgens Van Selms sou Jeremia waarskynlik graag wel wou hê dat Gananja se profesie bewaarheid word, ook al sou dit ten koste van sy eie reputasie wees.

\section{Dan stel Jeremia egter sy saak:}

Gananja, jy en die hele volk weet tog dat daar ook ' $n$ ander teologiese en profetiese tradisie is wat sê: ware profete verkondig meesal oorlog en rampe en peste. Nie voorspoed soos jy nie. Profete wat voorspoed verkondig het, was net ware profete as hulle woord waar geword het, maar jy Gananja ... (Jer 28:6-9)

Op hierdie punt onderbreek Gananja Jeremia toe hy die houtjuk voor almal stukkend breek. Daarna sê Jeremia kort en kragtig (Jer 28:13-14): 'Gananja jy breek houtjukke stukkend, maar in die plek daarvan sal jy ysterjukke dra. Die oordeel oor julle sal nie afneem nie, maar groter word.' Hy gaan voort (Jer 28:15-16): 'Gananja jy gaan die eerste wees wat getref word. Voor die einde van dié jaar gaan jy dood wees.'

Profeet kom teen profeet te staan, godsman teen godsman. Dit is 'n kwessie van 'bevestig' en 'kritiseer' (Van der Westhuizen 2008:191). 'So sê die Here die Almagtige die God van Israel,' sê die een. 'So sê die Here, die Almagtige die God van Israel,' sê die ander een. Watter God praat met watter profeet? Of praat God hier teen God? Dit is duidelik nie ' $n$ maklike vraag om te beantwoord nie. Elke mens wat geroep is om die Woord van die Here te verkondig, worstel met die vraag of dit die eie menslike woorde of die Here se boodskap is wat hier uitgespreek word. Watter kriteria kan aangewend word om God se woord van mensewoorde te onderskei? Volgens Van der Woude (1970:13-20) is daar in die Ou Testament self meer as een kriterium wat gebruik kan word om tussen ware en valse profesie te onderskei. Myns insiens is daar drie moontlike maatstawwe. Om ' $\mathrm{n}$ antwoord te ken, sal egter nie noodwendig die spanning ontlont nie. Dit laat waarskynlik eerder die spanning toeneem.

In die eerste plek sou die onderskeid tussen die ware en die valse profeet alleen met die loop van tyd duidelik word. Die gang van die geskiedenis sal Gananja as die valse profeet en Jeremia as die ware profeet uitwys. Dit is egter 'n skrale troos vir die leser, want dit sou beteken dat ' $n$ mens eers oor 'n lang tydperk sal kan onderskei of dit God se woord of mensewoord was.

'n Tweede moontlikheid is om die dogmatiese inhoud van wat die profete sê, te ondersoek. Gananja verkondig 'n vinnige oplossing. Hy sê: 'Gryp die swaard, breek self die juk van Babel!' Jeremia, aan die ander kant, verkondig 'n stadige, pynlike oplossing. Hy sê: 'Laat die oordeel van die Here oor ons gaan, dan sal Hy self vir ons 'n toekoms bewerkstellig.' Selfregverdiging staan hier teenoor Goddelike regverdiging, eie beleid teenoor God se genade.

Hierdie teenstelling het telkens in die kerkgeskiedenis opgeduik. Paulus staan byvoorbeeld teenoor die dwaalleraars in Galasië. In die Romeine-brief verwys Paulus na die eiegeregtigheid van sy volksgenote wat teenoor die geregtigheid van God staan. Later in die geskiedenis kom Pelagius en Augustinus teenoor mekaar te staan (vgl. Bakhuizen van den Brink 1967.I:260-262). Nog later is dit die konflik tussen Rome en die Reformasie (vgl. Bakhuizen van den Brink 1967.III:11e.v.). Dit is maar enkele voorbeelde uit die geskiedenis.

Indien dogmatiese inhoud as kriterium aangewend word, is die vraag of die profete vóór Gananja wat in die Sionstradisie gestaan het, ook almal gedwaal het. Sou hulle op grond van 'n dogmatiese kriterium as ketters afgemaak kon word? Sekerlik nie. 
Die derde moontlikheid is dat die onderskeid tussen die twee profete in hulle tydsberekening lê. Gananja lees die tyd verkeerd. Hy misgis hom met die uur. Die inhoud van sy boodskap is in orde, maar dit word op die verkeerde tydstip gebring. Hy roep 'vrede, vrede' terwyl God se uur vir vrede nog nie aangebreek het nie. Hy spreek tydlose waarhede uit, maar doen dit ontydig en daarom is dit vals. Hy verkondig ' $n$ teologie wat in die verlede ' $n$ goeie teologie was vir die tyd, maar in sy mond verword dit tot ideologie (kyk Smit 1985:102-104). Die waarheid word so goed soos fiksie.

Die natuurlike menslike reaksie sou wees om simpatie met Gananja te hê. Mense wil God nie altyd graag in hulle uur hê nie. Mense is geneig om 'n werklike ontmoeting met God van aangesig tot aangesig steeds te probeer ontwyk. Mense voel dikwels gemakliker met die formele Woord van God, solank dit by woorde bly, niks van mense verg nie en hulle doen en late goedkeur. Solank die woord van God sê wat mense wil hoor, is hulle tevrede.

Die vraag is dan of gelowiges nog so praat dat mense, die wêreld, kan hoor wat God sê. Dit is juis die doel van die gawe om God se boodskap te verkondig. Met die kritiese insig van die kunstenaar wat kerk en teologie van buite af waarneem, laat die Afrikaanse skrywer, Chris Barnard (1992:58), in sy roman Moerland een van die karakters die volgende sê: 'Die Afrikaanse predikante praat op so 'n manier dat 'n mens later nie meer ' $n$ woord kan hoor wat die Here sê nie' (Barnard 1992:58). Die skrywer wys die moontlikheid uit dat die kerk se profetiese stem dalk nie met die van God gesinchroniseer is nie.

Dit is die spanning waarmee Jeremia 28:1-17 worstel en waarmee die leser gekonfronteer word: Is dit God se stem of is dit mensewoorde? Hierdie spanning is waarskynlik noodsaaklik omdat dit mense terugbring tot gebed, tot ' $n$ waaragtige soeke na God se woord wat nie net letters op papier is nie, maar die lewende God van die Woord wat self aan die woord kom.

Op dié wyse kan gelowiges leef in die verwagting dat God hulle op God se tyd deur die Woord tot gehoorsaamheid sal bring. Dit is waaroor die gawe om God se boodskap te verkondig, ten diepste gaan. Hierdie uitdaging word gerig aan almal wat die woord van God verkondig en ook aan toekomstige verkondigers van die woord. Die verkondiging sal altyd binne die konteks van spanning en keuse geskied. Oor die spanning word spesifiek in die tweede noot van die akkoord besin. Die keuse is die derde noot van die akkoord.

\section{Die tweede noot: Matteus 24:3-14}

In Matteus 24 vind 'n besondere gesprek tussen Jesus en sy dissipels plaas (kyk Garland 1993:234). Hierdie gesprek het bepaalde implikasies vir ons tyd. Jesus kondig vernietiging aan en in Matteus 24:3 vra sy volgelinge wanneer dit sal gebeur. Jesus en sy dissipels was by die tempel, simbool van die vaste, onwankelbare godsdiens en geloof van 'n trotse nasie. Matteus fokus op die tempel as manjifieke konstruksie.
Jesus se reaksie is egter vir die hoorders en lesers skokkend en onverwags: 'Julle sien al hierdie dinge? Dit verseker Ek julle: Hier sal nie een klip op die ander bly nie; alles sal afgebreek word' (Matt 24:2). Sy volgelinge wil weet wanneer al hierdie dinge gaan gebeur en wat die tekens van Jesus se koms en van die einde van die wêreld sal wees.

Jesus begin sy rigtinggewende gesprek met 'n waarskuwing: Pasop dat niemand julle mislei nie. Daar sal baie disinformasie en leuens en misleiding wees. Hierdie 'pasop' word in vers 6 herhaal: Daar is ' $n$ tweede gevaar. Dit is die gevaar van verskrikking, van angstigheid en van die vrees vir wat mag kom. Disinformasie verlei en vrees verlam. Albei het afbrekende gevolge vir enige saak.

Die lys van sake wat die dissipels in die toekoms te wagte kan wees, is egter beangstigend en verwarrend: valse Christusse, die rumoer van oorloë en gerugte van oorloë, die een nasie wat teen ' $\mathrm{n}$ ander te staan kom, die een koninkryk teen 'n ander, hongersnode, aardbewings, vervolgings, afvalligheid, verraad, haat, valse profete, minagting van die wet van God en die liefde wat by baie verkoel. Dis is hoe die eindtyd sal wees. Katastrofe na katastrofe sal mense en hulle leefwêreld soos skokgolwe tref.

Oor die presiese betekenis van hierdie woorde van Jesus is reeds heelwat gedebatteer (kyk o.a. na Davies \& Allison 2004:309-310). Een vraag is byvoorbeeld wanneer dit alles histories gesproke in vervulling sou gaan (kyk na Keener 2009:573-575). Sommige meen dat hierdie hele lys tekens in vervulling gegaan het toe Jesus gekruisig is. Ander meen weer dat hierdie woorde in 70 n.C. in vervulling gegaan het toe die tempel in Jerusalem deur die Romeine in reaksie op die opstand van die Judeërs verwoes is. Nog ander meen dat al hierdie dinge eers aan die einde van die wêreldgeskiedenis vervul sal word. Moontlik is aspekte van al hierdie sienings geldig. Nolland (2005) vat die kern daarvan soos volg saam:

When Jesus' view that the intervention of God in the world had reached a decisive stage in connection with his own ministry is linked with his experience of the substantial rejection of his ministry, especially by the leadership classes, it becomes difficult not to attribute to him some such expectation of impending judgment. (bl. 957)

Nolland bevestig dat die tekens van die einde dwarsdeur Jesus se lewe teenwoordig was, vanaf sy verwerping as pasgebore kind, tot en met sy kruisdood. Die ellendes wat Matteus op Jesus se lys laat aanteken, gaan oor en oor in vervulling, nie net in die lewe en dood van Jesus nie, maar ook in die lewe en verwerping van die evangelis en sy lesers, asook in die lewe en bediening van die latere verkondigers van die evangelie. Soos eb en vloed kom dit en gaan dit, soms meer en soms minder, soos rimpelings wat al wyer deur die geskiedenis heen uitkring. Soms lyk dit of dit selfs in intensiteit toeneem.

Hedendaagse lesers van die teks leef ook êrens te midde van hierdie rimpelings. Só ' $n$ tyd, die eindtyd, is die huidige tyd ook. Hierdie oor en oor gebeur van die eindtyd behoort 
egter nie verstaan te word volgens die Griekse Stoïsyne ideaal dat einde en nuwe begin 'n voortdurende vernuwing veronderstel nie. Matteus se Jesus het die herskepping van die kosmos in gedagte. Hoewel sy lesers en ook vandag se lesers te midde van die rimpelings van die kom en gaan van ellendes lewe, is die herskepping ' $n$ gebeure wat slegs 'n 'single end time event' (Sim 1996:112) veronderstel. Uitgelewer aan die wisseling van omstandighede, het Jesus se lewe, sy begin en sy einde, ' $n$ beslissende uitwerking op sy volgelinge. Hulle lewe in die eindtyd het reeds aangebreek (kyk na Van Aarde 2010:35-63).

Die vraag van hedendaagse lesers sou kon wees of ál die tekens van die einde nie elke dag op die een of ander manier in vervulling gaan nie. Die minagting van die wet en die verkoeling van die liefde is duidelik in hierdie wêreld sigbaar. In ' $n$ gesekulariseerde samelewing word nie aan God se riglyne vir die lewe gehoor gegee nie. As God se wet sê 'jy mag nie moord pleeg nie', toon koerantopskrifte die werklikheid van geweld op geweld.

God roep mense om in hierdie wêreld anders te leef. Aan al die volgelinge van Jesus, vanaf die eerste dissipels tot vandag, word die woorde gerig: 'Maar wie tot die einde toe volhard, sal gered word.' Hierdie woorde is egter vatbaar vir misverstand en is in die loop van die kerk se geskiedenis soms verkeerd vertolk.

Sommige meen dat mense opgeroep word om deur middel van hulle eie pogings (volharding) hulleself te red. In die Nuwe Afrikaanse vertaling van Lukas 21:19 word byvoorbeeld 'n imperatief gebruik: 'Deur julle volharding moet julle julleself red' (outeur se eie beklemtoning).

Die bedoeling is egter nie dat mense deur hulle eie inspanning hulle eie verlossing moet bewerk nie. Van die 'tekens van die eindtyd' word reeds in die Ou Testament berig. Turner (2008:573) maak 'n lys van verwysings na sulke tekens in sowel die Ou- as die Ou-Testamentiese apokriewe, insluitende werke soos dié van Josefus. Dit kom voor in gedeeltes wat beklemtoon dat die huidige tyd besonder sleg is - so boos dat alles wat in hierdie wêreld vir mense sekuriteit bied, in totaliteit vernietig sal word, hetsy deur aardbewings, oorloë en burgeroorlog, of watter ander ramp ook al. Al wat in sulke desperate en neerdrukkende omstandighede vir die mens oorbly, is totale oorgawe aan God se beskerming (kyk na Van Aarde 2010:35-63). Die tekens van die eindtyd het dus vanaf die Ou-Testamentiese tyd tot in Jesus se tyd die tekens geword wat heenwys na God se ingrype in hierdie bose wêreld deurdat Hy die Messias gestuur het. Borg en Crossan (2006:174) noem dit 'God's great clean-up of the earth'. Volgens die evangelis Matteus is Jesus hierdie Messias. Daarom bely Petrus: ' $U$ is die Christus, die Seun van die lewende God' (Matt 16:16; kyk na Verheyden 2011:263-312).

Soos Petrus, hoor diegene wat vandag op die punt staan om as predikante van die Nederduitsch Hervormde Kerk van Afrika gelegitimeer te word, Jesus se woord as antwoord op hulle onderskrywing van die belydenis: 'Gesëend is jy, Simon bar Jona, vlees en bloed, geen mens, kan jou tot hierdie belydenis bring nie! Net God die hemelse Vader' (Matt 16:17). Die woord 'geseënd' wil iets uitdruk van 'gelukkig, salig'. Dit verwys na daardie mens wat weet hoe afhanklik sy of hy van God is (vgl. Matt 5:3). Davies en Allison (2004) stel dit soos volg:

The 'in heart' of 5.8 and 'meek and lonely in heart' of 11.29 argue that the spirit is the sphere of poverty. The emphasis is not simply on external conditions but on internal disposition ... The outcome of the last judgement is here proclaimed. (bl. 444-445)

Om jouself te midde van die tekens van die eindtyd te red, is nie om te meen dat ' $n$ mens oor kragte en vermoëns beskik wat nietige mense nie het nie. 'Red jouself deur volharding' beteken om God se teenwoordigheid in Jesus die ware Christus te herken en erken. Dit is om jou sekuriteit nie te soek by 'valse christusse' of verleidelike menslike sekuriteite soos tempels wat van klip gemaak is nie. Dit gaan daarom dat die mens God se teenwoordigheid sal soek in Jesus wat volgens die Evangelie van Matteus van Homself gesê het: 'Hier is Ek, die Een wat meer en groter is as mensgemaakte tempels' (Matt 12:6). Geen mens met selfinsig kan meen dat dit moontlik is om hom- of haarself te red nie (vgl. Van Aarde \& Dreyer 2011:8). Enige mens wat die geloofstryd stry, weet hoe moeg mense in die stryd kan word, hoeveel oomblikke van vertwyfeling oor hulle kom en hoe moeilik dit kan word om in die geloof te volhard. Jesus se oproep om tot die einde toe te volhard, gee nie te kenne dat mense volmaak is nie. Jakobus 3:2 stel dit duidelik dat almal in baie opsigte ver te kort skiet, struikel en val.

Die vraag is wat volharding dan beteken, ook vir diegene wat hulle geroepe voel om in Christus, wat vir hulle gely het, se voetspore te volg. Wat beteken dit dat mense wat tot die einde toe volhard, gered sal word? Die saak het twee kante. Die eerste is die duidelike opdrag om as dissipels van Jesus Christus in die liefde te volhard. Sulke volgelinge van Jesus sal nie meedoen aan die minagting van die wet en die verkoeling van die liefde nie. Om te volhard, beteken om lief te hê en te bly liefhê al voel dit asof die oormag groot is en alle menslike pogings geen verskil maak nie. Wie in sulke omstandighede volhard, word sélf ' $\mathrm{n}$ teken van die einde en bring die einde nader. Volgens Matteus 24:14 het Jesus gesê: 'En hierdie evangelie van die koninkryk sal in die hele wêreld verkondig word, sodat al die nasies die getuienis kan hoor ...'

Wat nodig is in kerk, in die land en in die wêreld is mense wat volhardend goed doen, wat volhardend die lig versprei, wat volhardend warmte bring waar koue liefdeloosheid heers, wat volhardend meewerk aan die singewing, die betekenis, dat God se koninkryk in die Messiasryk van Jesus Christus aangebreek het (kyk na Van Aarde 2008:163-182). Waar Jesus volgens die Evangelie van Matteus gesê het dat Hy die ware tempel, die ware beliggaming van God se teenwoordigheid is (Matt 12:6), het Hy van sy volgelinge deernis, dit wil sê barmhartigheid en liefde, verwag. Hy vra nie offers soos die mense wat God in tempels van klip gesoek en 
hulle heil op mensgemaakte dinge gebou het nie (Matt 12:7). Juis omdat dit nie maklik sal wees nie, het Jesus die woord volharding gebruik.

Volharding het ook 'n ander kant. Dit is om die tyd waarin 'n mens leef, te evalueer in die lig van hierdie einde waarop Jesus se gesprek gefokus het. Dit is om te verstaan dat die tekens van die tye nie net ' $n$ lang lys verskrikkings verteenwoordig nie. Dit is ook die tekens van die voorspel tot die einde. Die dinge wat gebeur, is nie 'n doel op sigself nie, maar is geboortepyne. Dit is tekens van die begin van ' $n$ nuwe tyd.

Om te volhard, beteken dan nie ' $\mathrm{n}$ reeks handelinge voor God om jouself te probeer regverdig nie. Dit is eerder om te leef in die vaste wete dat God aan die werk is. God se nuwe hemel en nuwe aarde word gebore en mense sug saam met die skepping in die pyne van verwagting dat die nuwe dag gou sal aanbreek (Rom 8:22-23). Dit is nie net die volharding van die heiliges nie, maar eerder ' $n$ volharding in die gees van die missio Dei: Dit is die volharding van God met die heiliges.

Vandag is vir mense 'n spanningsvolle tyd, gevul met krisisse en lyding. Die lewe en die bediening verg volharding. Om te volhard, is om ' $n$ keuse te midde van spanning en lyding uit te oefen. Wat hierdie keuse behels, word in die derde noot van die akkoord bespreek.

\section{Die derde noot: Lukas 23:26-43}

Dit is ' $n$ vraag of die evangelie van Jesus Christus werklik kragtig is en kragtig in mense se lewens werk. Indien die vraag bevestigend beantwoord word, roep dit 'n volgende vraag op, naamlik wat die krag van die evangelie in gelowiges se lewens behels. Dit gaan oor wat anders is in mense se lewens omdat hulle die evangelie glo. 'n Saak kan daarvoor uitgemaak word dat niks eintlik anders nie. Die werklikheid is dat, hoewel die grootste persentasie mense in Suid-Afrika hulleself as Christene beskou, daar steeds op groot skaal misdaad, konflik, VIGS en armoede voorkom. Selfs mense wat kerke getrou besoek, steeds ly aan die moderne 'siekte' van stres en spanning. Die vraag bly dus wat 'anders' sal wees as Christene werklik die evangelie van Jesus Christus hoor.

Die teks vir die preek is wat Jesus volgens Lukas vir 'n misdadiger gesê het wat langs Hom aan ' $n$ kruis gehang het: ‘Ek verseker jou: Vandag sal jy saam met My in die paradys wees'. Dit is belangrik om daarop te let dat Jesus sê: 'Vandag!' Hy verwys nie na die toekoms nie, maar na die onmiddellike - vandag (vgl. Wolter 2008:761).

Die vraag is wat hierdie woorde beteken het vir die persoon wat tóé langs Jesus aan die kruis was en wat dit beteken vir die gelowiges van vandag wat te kampe het met moeilikheid en lyding en wat daardeur oorweldig word. Die ervaring is dikwels dat die chaos in hierdie lewe so groot is dat niemand kan help nie. Vir baie mense, ook vir diegene wat hulle geloof in die drie-enige God bely, kan dit voel asof die kwaad in beheer is. Die enigste hoop lê dan in die toekoms - 'eendag in die hemel' wanneer alles in God se hande sal wees. Dan sal dit beter gaan. Volgens Lukas hoef die gelowige egter nie te wag totdat die chaos 'eendag' tot 'n einde kom nie. God het nóú reeds beheer. Gelowiges is nie magteloos of hulpeloos en reddeloos aan die chaos uitgelewer nie. Wat gelowiges kan doen, volgens die boodsckap van Lukas, is om soos daardie misdadiger te bid: 'Jesus dink aan my wanneer $U$ in u koninkryk kom.'

Die woorde 'dink aan $\mathrm{my}^{\prime}$, is dieselfde as 'onthou my' in die gebed van Psalm 89:50 (vgl. Weiser 1962:587): 'Dink Here, aan die smaad wat my aangedoen is; aan alles wat ek moes verduur van baie volke'. 'n Ander interpretasie is egter ook moontlik, naamlik dat die mens God verwyt: 'Besef U ...?'

Daar is dus twee moontlike maniere om lyding en chaos en wanhoop te hanteer. Die twee misdadigers weerskante van Jesus aan die kruis verteenwoordig die twee keuses. Die een bid: 'Dink aan my Here ...' Die ander word kwaad en verwyt. Die een wat kwaad word, is soos 'n dier - so 'n mens probeer sigself red maar slaag nie daarin nie.

Lukas is die evangelis wat in die besonder die geestelike worsteling van gelowiges ten tye van vervolging en martelaarskap uitbeeld (kyk na Schmithals 1980:32-33). Hy skep vir die leser 'n ervaring van die magteloosheid wat die eerste gelowiges moes beleef het. Hulle het onwrikbaar aan die lewende God van hemel en aarde geglo, die God in wie se hand alles is, maar in die arena het die Romeinse pantserwa met die skerp speke aan die wiele hulle stukkend gesny en oopgekloof sodat hulle bloeiend en nakend daar gestaan (het) wanneer die luike van die hokke oopgemaak is en die honger roofdiere op hulle afgestorm het. Hulle kon nie veg of hulle teësit nie. Hulle was die slagoffer, die prooi. Hulle vraag was waar God in die chaos is. Dit is steeds die vraag waarmee baie mense, wat vandag ly en swaarkry, worstel: 'Waar is God in my swaarkry?'

Lukas is sterk beïnvloed deur Paulus. Paulus beskryf die krag wat daardie vervolgde gelowiges gedra, gesterk en getroos het. Dit is steeds die krag wat gelowiges vandag dra. In 1 Korintiërs 15 argumenteer Paulus dat saad wat geplant word, eers moet sterf, tot niet gaan, voordat dit ontkiem en vrug dra. Die vrug gee troos, krag en hoop vir die lewe hier en vir die toekoms, want die troos is Christus. Dit is die wete dat hy die oorwinning in Christus kon bereik, wat Paulus in staat gestel het om, ten spyte van sy lyding en swaarkry, steeds te weet dat sy diens aan die Here die pyn en lyding werd was, want hy kon deel kry aan die volle oorwinning van Jesus Christus.

Die 'filosoof van die pessimisme', Nietzsche (1844-1900), het teen die agtergrond van 'n skildery van die skilder Vincent van Gogh, bekend as Starry night, oor homself gesê: Alleen die mens wat van die chaos in sy of haar eie hart weet, kan die dansende sterre sien (vgl. Shiff 1988:25-48; Van Aarde 
2003:5). Van Gogh het hierdie skildery in 1889 in sy stryd teen ondraaglike liggaamlike pyn gemaak. Uiteindelik het Van Gogh by die punt gekom waar hy nie meer teen die pyn kon of wou stry nie. Hy het sy oor afgesny en uiteindelik selfmoord gepleeg. Die filosoof Nietzsche het op grond van hierdie skildery gesê dat daar vir alle mense twee moontlikhede is, naamlik om teen God te draai of om ten spyte van die donker nag van die lewe op die dansende sterre te fokus. Slegs die mens wat bewus is van die chaos in die eie hart, kan egter die dansende sterre sien.

Die vraag is of mense genoegsaam van die chaos in hulle eie binneste bewus is. Henri Nouwen (1971:16) waarsku teen wat hy scotosis noem: 'Scotosis means an aberration which prevents the emergence into consciousness of perspectives that would give rise to unwanted insights.' Mense probeer dikwels alles in hulle vermoë doen om te verhinder dat hulle eerlik en diep na binne hoef te kyk. Soms is die nuttelooste begeertes die grootste dryfkrag in mense se lewens. Die versoekings wat Jesus in die woestyn weerstaan het, is dikwels wat sy volgelinge die meeste begeer (vgl. Nouwen 1971:69-77). Voordat mense nie werklik verstaan hoe donker en sondig dit is wat hulle diep binne-in dryf en wat hulle werklik voel en doen nie, sal hulle nie die dansende sterre kan sien nie. Mense wat nie hulle eie geloof én twyfel, hulle wanhoop én hoop, hulle vrese én vreugde verstaan nie, sal moeilik die skoonheid van die dansende sterre teen agtergrond van die diep duisternis kan waardeer. Selfondersoek is egter nie maklik nie. Mense is dikwels selektief wanneer dit by selfondersoek kom. Volgens Nouwen (1971:16) is dit juis daar waar mense se blinde kol is (Nouwen 1971:16).

Die heel eerste martelaarsverhaal wat Lukas vertel, is van Stefanus se steniging (Hand 7; kyk na Wolter 2008:757). Volgens Lukas het Stefanus, toe hy besig was om te sterf, gesê: 'Here Jesus ontvang my gees'. Hierin kan Jesus se sterwenswoorde herken word. 'n Martelaar wat gestenig word, kan, as die eerste klip tref, ophou om te getuig, of kan met die laaste asem sê: 'Kyrie Jesu, Here Jesus ontvang my gees.' In die woorde van Jesus, volgens die evangelis: 'Vader, in $u$ hande gee Ek my gees oor.' Óf die sterwende kan God vloek en ontevrede probeer om hom- of haarself te red.

Die twee misdadigers, sondaars aan die kruise weerskante van Jesus, se kruis is simbool van die twee moontlikhede. Paulus, Stefanus en Jesus, wie se pyn nie ophou nie en wie se situasie nie verander nie, sien soveel meer raak as net hulle eie lyding. Teen die donker nag sien hulle die dansende sterre raak.

In die Ou Testament word in Sagaria 12:10-11 (vgl. Ps 89:39) beskryf hoe die koning eers verneder moet word voordat hy gekroon kan word (kyk na Frye \& Macpherson 2004:68; vgl. Van Aarde 2003:11). Die koning word deur die priesters beledig, word op die wang geslaan, word van sy septer en koningsklere gestroop. Eers nadat sy onskuld bewys en bevestig is, dat hy nie aan geweld, oorlog en moord skuldig was nie, vind sy kroning as nuwe koning plaas. Die evangelis Lukas beklemtoon die onskuld van Jesus, die lydende martelaar (Leaney 1971:287). Die een misdadiger neem aan die belediging van Jesus deel en die ander een wys op Jesus se onskuld. Hy sê:

Is jy nie bang vir God nie? Jy ondergaan tog dieselfde straf as hierdie man! In ons geval is dit regverdig want ons ontvang die verdiende straf vir ons dade. Maar hierdie man het niks verkeerd gedoen nie. (Luk 23:40)

In die kruisigingsgebeure speel die ou verhaal af van hoe die koning eers verneder moet word en dan, nadat hy onskuldig bevind is, gekroon kan word. In Jesus se verhaal is dit ' $n$ doringkroon waarmee Hy tot ewige Koning gekroon word. Ook by Stefanus is daar sprake van 'n kroon, want sy naam beteken kroon. Dit is asof Stefanus 'n voortsetting is van die keuse van die een misdadiger aan die kruis wat kies om hom op God te beroep - die een wat reg kies, wat die dansende sterre sien al is die nag vir hom besonder donker. Stefanus sê: Ek sien die hemel geopen en Jesus aan God se regterhand, ... Here Jesus ... ontvang my gees.

Die vroue wat by die kruis huil, is vroue wat nie kinders in die lewe gebring het nie. Menslik gesproke is daar niemand wat vir hulle sal kan sorg nie (kyk na Wolter 2008:755). Kinders was mense in die Bybelse kulture se toekoms. Kinders was hulle troos in moeilike lewensomstandighede. Ook wanneer hulle in die doderyk nie meer in God se teenwoordigheid kon wees nie, sou hulle kinders die lewe voortsit. Sonder kinders was daar vir hulle geen toekoms nie en die gevolg was volslae wanhoop. Die vroue by die kruis slaan hulleself op die bors as uitdrukking van hulle wanhoop. Ook die misdadigers aan weerskante van Jesus aan die kruis hang daar sonder hoop. Wat aan die kruis gebeur, speel ook onder die kruis af. Die keuse bly egter vir almal dieselfde. Dit is die keuse tussen die voortbestaan van chaos in hierdie lewe of deel hê aan die oorwinning wat begin by die uitroep: 'Kyrie Jesu - Here Jesus dink aan my.'

Die keuse neem nie die lyding weg nie. Die misdadiger wat hom op Jesus beroep, sterf daar aan die kruis. Die klippe hou nie op om op Stefanus te reën nie. Alles bly dieselfde, maar tog verander alles radikaal.

Die boodskap is gefokus op die hede, nie die toekoms alleen nie. Vandag is daar iets persoonliks, iets reëels teenwoordig. Vandag breek die fontein van nuwe lewe oop, die droë moederskoot gee geboorte. Jesus se lyding het 'n nuwe begin moontlik gemaak. Alles is anders. Leo Tolstoy (1828-1910), die beroemde Russiese skrywer, het vyf jaar nadat hy 'n Christen geword het, aan die hand van Lukas 23:43 teruggedink aan sy bekering en die radikale verandering in sy lewe (Tolstoy 1997:111; vgl. Van Aarde 2003:11). Op grond van die nuwe begin van die misdadiger aan die kruis - 'vandag sal jy saam met My in die paradys wees' - het Tolstoi nie meer begeer wat hy voorheen wou gehad het nie. Hy gebruik die voorbeeld van iemand wat op reis was om sake te doen, maar skielik besef het dat dit nie meer nodig is nie en teruggekeer het huis toe. Die rigting van sy lewe het radikaal verander. Tolstoi beskryf hoe hy self was soos die kwaaddoener wat aan die kruis hang en Jesus saam met hom daar sien hang. Dit het sy lewe verander. 
Lukas se boodskap is nie dat omstandighede sal verander nie. In die Suid-Afrikaanse konteks sal, byvoorbeeld, plaasmoorde, siekte, spanning en die chaos wat heers, nie verdwyn wanneer gelowiges die kerkgebou verlaat nie. Tog kan iets verander, soos in die lewe van Tolstoi, soos in die lewe van Stefanus, soos in die lewe van Paulus. In die donkerste nag kan die gelowige op die dansende sterre fokus en vanuit die chaos roep: 'Jesus dink aan my ...' en Jesus hoor antwoord: 'Ek verseker jou vandag, vandag sal jy saam met in die paradys wees.' Die vrede, vreugde en hoop wat die evangelie van Jesus Christus bring, maak reeds in die hede die lewe sinvol en betekenisvol. Dit beteken dat gelowiges met hoop en egte liefde kan lewe, ongeag die omstandighede.

Die twee misdadigers wat saam met Jesus gekruisig is, verteenwoordig twee keuses. Die een ly en sterf met chaos in sy hart. Die ander een ly en sterf met ' $n$ lied in sy hart. Psalm 30:12 verwoord hierdie ervaring treffend:

Ek was in rou, maar $U$ het my van vreugde laat dans, $U$ het my rouklere uitgetrek en vir my feesklere aangetrek, daarom sal ek sing tot $\mathrm{u}$ eer; ek sal nie stilbly nie, Here my God, vir altyd sal ek U loof.

\section{Slotakkoord}

Die drie homilieë is aangebied as drie note in ' $n$ akkoord. Die lesers, die hoorders, harmoniseer verder wanneer hulle hierdie getuienis voortdra na waar hulle in die spanning van die keuse tussen waar en vals leef. Dié wat die lied bo die chaos kies, maak 'n keuse vir God se teenwoordigheid in Jesus Christus. Hulle kies om as dissipels van Jesus te volhard en hulle kies om ten spyte van en te midde van die kilheid, koudheid en wreedheid van hierdie wêreld hulle geloof in Christus te leef. Hulle kies om te midde van die chaos van hierdie lewe hulle op die Here te beroep.

Die keuse is 'n geloofsonderskeiding, 'n discernment (vgl. Marais 2007:34-37). Die term discernment 'kom van die Latynse woord discerne wat beteken "om te skei"' (Marais 2007:34), letterlik om in ' $n$ krisis deur toetsing 'n onderskeid tussen goed en kwaad te tref.

In die Nuwe Testament word verskillende Griekse woord gebruik om die onderskeiding in die geloof te beskryf. In 1 Korintiërs 12:10 word die woord diakrisis gebruik om te verwys na die gawe om tussen geeste te onderskei. In Johannes 5:30 en 1 Korintiërs 4:5 word krino gebruik om regspraak aan te dui - die onderskeiding tussen reg en verkeerd, tussen waarheid en leuen. Romeine 12:2 en Filippense 1:10 gebruik dokimazo vir die denkproses waarmee 'n saak ondersoek of getoets en 'n nuwe insig ontdek word.

Volgens Marais (2007:34) word met die Griekse woord phronesis die vermoë om 'n saak met wysheid te oorweeg (letterlik: om te bedink) en tot 'n praktiese besluit te kom, beskryf - onderskeidingsvermoë dus. In Lukas 1:17 beteken dit om die regte pad te vind en in Efesiërs 1:8 beteken dit om met die regte insig te leef.
Enkele verse verder koppel Paulus phroneo aan Christus. Sommige vertalings (soos die 1983-vertaling) vertaal phroneo in dié geval met 'gesindheid' (Fil 2:5) om aan te toon dat dit hier om meer as net denke gaan. Dit is 'n aksie wat deur die denke, strewe en gesindheid van Christus gevorm word (in Rom 11:34 praat Paulus van die 'gedagte van die Here'; vgl. die 1953 vertaling; Marais 2007:35).

Die onderskeiding waarna hier verwys word, is wanneer nagedink word en sake in die lig van Christus se waardes beoordeel word. Dit is om Christus as vertrekpunt te neem en uit te kom by ' $n$ beslissing wat God sal verheerlik. Dit gaan nie oor 'n spesifieke antwoord op ' $n$ vraag nie, maar oor 'n manier van dink.

In die lig van Filippense 2:5-11 is geloofsonderskeiding ten diepste ' $n$ keuse vir selfontlediging en diensbaarheid - om te kies vir die kruis. Onderskeiding is derhalwe 'n geloofspraktyk, 'n manier van dink. Telkens wanneer gelowiges oor sake nadink, die Woord lees met die doel om só weer op Christus se spoor te kom, kies hulle om die kruis in hulle lewe konkreet te maak.

Lesers en hoorders van die teks wat lid is van geloofsgemeenskappe wat 'geroep is ... om in die voetspore van Christus te volg' (1 Pet 2:21), sal nie anders kan as om op grond van die Woord, sáám onder leiding van die Gees te onderskei wat die wil van God vir die pad vorentoe is nie. Smit (1985) haal Miroslav Volf in hierdie verband soos volg aan:

If Christian theology is to offer guidance for life in the contemporary world it will have to tackle (this) task: it will have to show how human work in complex and fast-changing industrial and post-industrial societies can be done in response to the gifts and callings of the triune God, the Creator, the Reconciliator, and the Redeemer. (bl. 8)

Gelowiges wat weekliks opdaag by eredienste om te aanbid en na die prediking luister, probeer om hulle lewe in God se teenwoordigheid te lei en om aan hulle roeping getrou te bly. Die vraag is of die teologie en die kerk, die eredienste en die prediking hulle in hierdie komplekse saak die nodige leiding bied.

Die verlamming en interne stryd wat die NHKA tans ervaar, lei tot verwarring onder lidmate wat gewoon probeer om in opregtheid voor die aangesig van die lewende God en getrou aan hulle roeping te leef. My voorganger, Theuns Dreyer, skryf die huidige tumult toe aan wat hy noem die kwantumsprong wat die NHKA geneem het om gehoor te gee aan die evangeliese eis om ' $n$ inklusiewe missionale kerk vir die toekoms te wees.

Smit (2001:24) onderskei tussen '... religiosity and spirituality. The first refers to religious conduct and the second to God's ongoing work of renewal.' Daarom is die subteks onderliggend aan die drie note van die akkoord wat ek hier aanbied vir die NHKA belangrik in die soeke na die pad vorentoe te midde van die teenswoordige politieke en 
teologiese woelinge. Die subteks word tussen die reëls gelees en ingevul. Dit is méér as net dat enkelinge die mag het om namens ander te besluit - dit sou neerkom op hiërargie. Dit is ook méér as net dat die mening van die meerderheid gelykgestel word aan die wil van God - dit sou neerkom op demokrasie. Dit is méér as net 'n reëlgebonde of tegniese benadering, waar orde en reëls die deurslag gee - dit sou neerkom op burokrasie (vgl. Robinson 2003:92-99).

Om in geloof te onderskei, behels ' $\mathrm{n}$ proses van bid en luister na God en mekaar, totdat die Gees ' $n$ oortuiging laat groei waarmee gelowiges vorentoe kan beweeg om die getuienis van die drie note in die akkoord voort te sit en verdere harmonieë te skep. Dit beteken om in die spanning van die keuse tussen waar en vals te leef. Dit is om God se teenwoordigheid in Jesus Christus te herken en te erken, en om te volhard as sy volgelinge wat kies om ten spyte van en te midde van die kilheid, koudheid en wreedheid van hierdie wêreld aan Hom getrou te bly. Dit is om te midde van die chaos van die menslike bestaan, soos daardie een misdadiger, te kies om jou op Jesus te beroep. Om gelowig te onderskei, is om sáám te bid en te luister en so sáám, luisterend, op die Here te wag.

\section{Erkenning \\ Mededingende belange}

Die outeur verklaar dat hy geen finansiële of persoonlike verbintenis het met enige party wat hom nadelig kon beïnvloed in die skryf van hierdie artikel.

\section{Literatuurverwysings}

Aalders, G.Ch., 1934, Het herstel van Israël volgens het Oude Testament, Kok, Kampen. Barnard, C.J., 1992, Moerland, Tafelberg, Kaapstad.

Bakhuizen van den Brink, J.N., 1967, Handboek der Kerkgeschiedenis, deel 1 en 3, Bert Bakker, Daamen N.V. Den Haag.

Borg, M.J. \& Crossan, J.D., 2006, The last week, HarperCollins, New York.

Crenshaw, J.L., 1983, 'A living tradition', Interpretation 37(2), 117-129. http://dx.doi. org/10.1177/002096438303700202

Davies, W.D. \& Allison, D.C., 2004, A critical and exegetical commentary on the gospel according Saint Matthew, vol. 3, T and T Clark, London.

Frye, N. \& Macpherson, J., 2004, Biblical and classical myths: The mythological framework of Western culture book, University of Toronto Press, Toronto.

Garland, D.E., 2003, Reading Matthew: A literary and theological comment on The First Gospel, Reading the New Testament Series, Crossroads, New York.

Keener, C.S., 2009, The Gospel of Matthew: A socio-rhetorical commetary, Eerdmans, Grand Rapids.
Leaney, A.R.C., 1971, A commentary on the Gospel according to St Luke, Blacks New Testament Commentaries, Adam and Charles Black, London.

Marais, F., 2007, God praat, leef luisterryk, Bybelkor, Wellington.

Nolland, J., 2005, The gospel of Matthew: A commentary of the Greek text, Eerdmans, Grand Rapids.

Nouwen, J.M.H., 1971, Creative ministry, Image Books, Doubleday, New York.

Roberts, J.J.M., 1973, 'The Davidic origin of the Zion tradision', Journal of Biblical Literature 92(3), 329-304, viewed 03 April 2012, from http://www.jstor.org/ stable/3263575

Robinson, A.B., 2003, Transforming congregational culture, Wm. B. Eerdmans, Grand Rapids.

Schmithals, W., 1980, Das Evangelium nach Lukas, Zürcher Bibel Kommentare, Teologischer Verlag, Zürich.

Shiff, R., 1988, 'Art history and the nineteenth century: Realism and resistance', The Art Bulletin 70(1), 25-48. http://dx.doi.org/10.2307/3051152

Sim, D.C., 1996, The apocalyptic escatology in the Gospel of Matthew, Society for New Testament Studies Monograph Series, Cambridge University Press, Cambridge. http://dx.doi.org/10.1017/CBO9780511555084

Smit, A., 2001, Meetings that matter: Leadership, spirituality and discernment in congregations, Lux Verbi. BM, Wellington.

Smit, D.J., 1985, 'Jeremia 28:1-17', in C.W. Burger, B.A. Müller \& D.J. Smit (reds.), Riglyne vir prediking oor die profete, pp. 98-106, Woord Teen Die Lig II/I, NG Kerkuitgewers, Kaapstad.

Tolstoy, L., 1997, The gospel in brief, ed. F.A. Flowers III, University of Nebraska Press, Lincoln.

Turner, D.L., 2008, Matthew, Baker Academic, Grand Rapids. (Baker Exegetical Commentary on The New Testament).

Van Aarde, A.G., 2003, 'Lydensmaand in Jerusalem', in Konteks, pp. 4-5, SENTIK, Kagiso Drukkers, Pretoria.

Van Aarde, A.G., 2008, 'Matthew's intertexts and presentation of Jesus as HealerMessiah', in T.R. Hatina (ed.), Biblical interpretation in early Christian gospels. Volume 2, The Gospel of Matthew, pp. 163-182, Library of New Testament Studies, 310, T\&T Clark, London.

Van Aarde, A.G., 2010, “'On earth as it is in heaven”: Matthew's escatology as the kingdom of heaven that has come', in J.G. van der Watt (ed.), Escatology in the New Testament, pp. 35-63, Wissenschaftliche Untersuchungen zum Neuen Testament, Siebeck Mohr, Tübingen.

Van Aarde, A.G. \& Dreyer, T.F.J., 2011, 'Die pendule subjektiwiteit-objektiwiteit in die teologie van Theuns Dreyer - 'n dialoog', HTS Teologiese Studies/Theological Studies 67(3), Art \#1172, 11 pages. http://dx.doi.org/10.4102/hts.v67i31172

Van der Westhuizen, A., 2008, 'Die gemeente as interpreterende gemeenskap in die preekmaakproses', DTh proefskrif, Departement Praktiese Teologie en Missiologie, Stellenbosch Universiteit.

Van der Woude, A.S., 1970, 'Ware en valse profetie in Israël', in G.C. Berkouwer \& A.S. van der Woude (reds.), Wat is waarheid?: Kernwoorden in het Christelijk geloof, pp. 13-20, J.H.Kok N.V., Kampen.

Van Selms, A., 1974, Jeremia, deel II, De prediking van het Oude Testemant, Uitgeverij G.F. Kallenbach B.V., Nijkerk.

Verheyden, J., 2011, 'Rock and stumbling block: The fate of Matthew's Peter', in D. Senior (ed.), The Gospel of Matthew at the cross-raods of early Christianity, pp. 263-312, Bibliotheca Ephemeridum Teologicarum Lovaniensum, CCXLIII, pp. 263-312, Bibliotheca
Uitgevery Peters, Leuven.

Weiser, A., 1962, The Psalms: A commentary, The Old Testament Library, SCM Press, London.

Wolter, M., 2008, Das Lukas Evangelium, Handbuch zum Neuen Testament, 5, Mohr Siebeck, Tübingen.

Yates, G.E., 2009, 'Isaiah's promise of the restoration of Zion and its canonical development', Liberty Universaty, Faculty publications and presentations, paper 231, viewed 02 April 2012, from http://digitalcommons.liberty.edu/Its_fac pubs/231 